\title{
Understanding How Terrorism is Financed
}

\subsection{What is Terrorism?}

According to the definition contained in the International Convention for the Suppression of the Financing of Terrorism drawn up in December 1999, the primary objective of terrorism is 'to intimidate a population, or to compel a Government or an international organisation to do or abstain from doing any act'. This is in contrast to other types of criminal activity where financial gain is generally the ultimate objective. While there is a difference in goals, terrorist organisations still require financial support in order to achieve their aims, and a successful terrorist group, like any criminal organisation, is therefore one that is able to build and maintain an effective financial infrastructure.

Terrorists and their organisations need finance for a wide variety of purposes - recruitment, training, travel, materials and setting up safe havens. Tracking, intercepting and strangling the flow of funds are vital elements of the global effort against terrorism.

The intelligence that can be gained about terrorist networks through knowledge of their financial transactions and dealings is vital in protecting national and international security and upholding the integrity of national and international financial systems.

\subsection{Characteristics of Terrorist Financing}

Terrorists often control funds from a variety of sources around the world and employ increasingly sophisticated techniques to move these funds between jurisdictions. In doing so, they draw on the services of professionals such as bankers, accountants and lawyers, and take advantage of a range of financial services products.

Although the total funds required by terrorist networks may be large, the funding required to finance individual terrorist attacks may be small. The US authorities have made an approximate estimate of the total cost of the planning and execution of the 11 September attacks in the USA of $\$ 200,000$. UK experience bears out the relatively low costs required for an effective terrorist attack. The 1993 'Bishopsgate bomb' in the City of London, which caused loss of life and over $£ 1$ billion worth of damage to property, is estimated to have cost only $£ 3,000$.

Detecting the transmission of such relatively small sums as they move through the financial system is challenging, especially before a terrorist attack takes place. Nevertheless, disrupting the transfer of financial support for terrorism makes it harder for terrorists to operate. Tracking the flow of funds also provides information on links, 
profiles and movements, which helps to build up an intelligence picture of the way in which terrorists and terrorist organisations operate.

\subsection{Sources of Terrorist Financing}

It is generally believed that terrorist financing comes from two primary sources. The first is the financial support provided by nation states or organisations with large enough infrastructures to collect and then make funds available to terrorists. This so-called 'statesponsored terrorism' has declined in recent years. Alternatively, an individual with sufficient financial means may also provide substantial funding to terrorist groups. Investigations have also revealed that some NGOs have been involved in the funding of terrorist activity.

The second major source of terrorist funding is legitimate or illegitimate revenuegenerating activity committed by terrorist organisations themselves. Criminality can provide a consistent revenue stream and terrorist organisations will choose activities that carry low risks and generate large returns. The following financing activities are typical.

\subsubsection{Extortion and Kidnapping}

This form of fundraising continues to be one of the most prolific and highly profitable. Monies are usually raised from within communities of which the terrorists are an integral part in return for 'protection', usually against the terrorists themselves. Over time, extortion comes to be regarded as a cost of doing business in communities where it is prevalent, and payments from individuals or businesses become essential to obtain the release of kidnapped family members, colleagues or employees.

\subsubsection{Smuggling}

Smuggling across borders has become one of the most profitable activities for terrorist organisations. Successful smuggling operations require co-ordination and established distribution networks through which smuggled goods can be sold for profit. The illegal smuggling profits are 'placed' into the banking system with the use of front companies or short-term shell companies that are dissolved after they have fulfilled their purpose. Alternatively, legitimate 'front' businesses may be used to pay in the smuggled funds as part of their normal turnover. In some cases businesses extorted by terrorist organisations are coerced into placing criminal proceeds.

\subsubsection{Drug Trafficking}

The proceeds of drug trafficking activity can be a highly profitable source of funds for terrorist groups and nation states that sponsor terrorism. Even if a terrorist group is not directly involved in the importation or distribution of drugs, they often profit from the activity by allowing drug suppliers and dealers to operate within the communities that they control, and through the imposition of levies. 


\subsubsection{Charities and Fundraising}

Community solicitation and fundraising appeals are a very effective means of raising funds to support terrorism. Such fundraising is often carried out by organisations which appear to have 'charitable' or 'relief' status. Fundraising activity may be targeted at particular communities where individuals either donate money knowing that it will be used for terrorist purposes, but more often believe that they are making a donation to a good cause. The charitable organisations to which they make donations often do, in fact, engage in some charitable work, in addition to acting as effective fundraising mechanisms for terrorism.

In line with the FATF recommendations, all countries are now required to take steps to prevent the misuse of charities for illegal purposes. Not all charitable or goodwill institutions, however, are as yet well regulated or required to maintain bank accounts. Charities are not required to publish full accounts of the projects that their fundraising efforts have helped to finance.

\subsubsection{Donations}

It is common practice within certain ethnic communities for amounts calculated as a percentage of income to be donated automatically to charity. Obviously it would be wrong to assume that such donations are either made with the intention of being of benefit to terrorists or that they are used for this purpose. Nevertheless, it must be recognised that both community donations and donations from wealthy private individuals and nation states that support terrorism are an important source of funding for many terrorist organisations.

\subsection{Laundering of Terrorist-related Funds}

As with other criminal organisations, terrorist groups will often attempt to obscure or disguise links between themselves and their funding sources. The methods used to achieve this objective are generally the same as for other criminal organisations (see Appendix A).

There have also been indications that some forms of alternative remittance systems, particularly the hawala system, play a role in the movement and laundering of terrorist funds.

Business relationships with individuals or entities that support or commit acts of terror will expose a financial services business to significant reputational, operational and legal risks. The risk is even more serious if the terrorists involved are later shown to have exploited ineffective systems of internal control or a lack of effective due diligence. The risk of funds intended to support terrorism entering the financial system can be reduced if financial services businesses apply satisfactory anti-money laundering strategies, particularly in respect of 'know your customer' procedures. 


\subsection{Recognising Terrorist Financing}

It is important that, as with suspicions of money laundering, there should be a statutory requirement for all financial services businesses to report cases where they have knowledge, suspicion or reasonable grounds to know or suspect that funds are related to terrorist organisations or terrorist funding.

However, because of the inherent difficulty in formulating a suspicion before an act of terrorism has occurred, particularly when funding has derived from a legitimate source, it is acknowledged that financial services businesses may be unable to detect terrorist funding as such. The only time that terrorist financing might be clearly identified is when a client is recognised as being on a published list of terrorist suspects or organisations. Most financial disclosures are in fact made on the basis of suspicion of criminality and may not appear to be directly related to the financing of terrorist activity. The number of suspicion reports based on suspected criminal activity that have resulted in the provision of valuable information about terrorist groups highlights evidence of the important links between crime and terrorism.

\subsection{Sanctions and Sources of Information}

International action against terrorist financing has focused on the following:

- Sanctions to cut off money flows to individual terrorists and terrorist organisations;

- Standards to stop the financing of terrorism;

- Technical assistance to help countries develop the measures and infrastructure necessary to root out the financing of terrorism.

The Terrorism (United Measures) Order 2001 contains, inter alia, strict liability offences of making any funds or financial services available to, or for the benefit of, terrorists.

In November 2001, the IMF issued a communiqué calling on all member countries to ratify and implement fully the UN instruments to counter terrorism. UN Security Council Resolutions 1267 (1999) and 1373 (2001) requested each member within its jurisdiction to:

freeze the assets of terrorists and their associates, close their access to the international financial system and consistent with its laws, make public the list of terrorists whose assets are subject to freezing.

In October 2003, FATF (see section 4.1.5) published a paper as a supplement to its eight special recommendations setting out international best practices for the freezing of terrorist assets which can be accessed on the FATF website (www.fatf-gafi.org). These best practices are based on the experiences of a number of jurisdictions, and are aimed at 
providing a benchmark for developing institutional, legal and procedural frameworks for an effective terrorist financing freezing regime.

The paper states that effective freezing regimes combat terrorism by:

(i) deterring non-designated parties who might otherwise by willing to finance terrorist activity;

(ii) exposing terrorist financing 'money trails' that may generate leads to previously unknown terrorist cells and financiers;

(iii) dismantling terrorist financing networks by encouraging designated persons to dissociate themselves from terrorist activity and renounce their affiliation to terrorist groups;

(iv) terminating terrorist cash flows by shutting down the pipelines used to move terrorist-related funds or other assets;

(v) forcing terrorists to use more costly and higher risk means of financing their activities, which makes them more susceptible to detection and disruption; and

(vi) fostering international co-operation and compliance with obligations under UN Security Council Resolutions 1267 (1999) and 1373 (2001).

The FATF best practice paper confirms that active participation and full support by the private sector is also essential to the success of any terrorist financing freezing regime. Consequently, it is advised that jurisdictions should work with the private sector to ensure its ongoing co-operation in developing and implementing an effective terrorist financing regime. 